\title{
The effects of extensification of sheep farming on the semi-natural vegetation of hill pastures
}

\author{
G. E. J. Fisher, G. E. D. Tiley and J. T. Wyllie \\ Scottish Agricultural College, Grassland and Ruminant Science Department, Auchincruive, Ayr KA6 5HW
}

\section{Introduction}

European Community subsidies and financial support from central government for hill sheep farming are being changed, reduced or withdrawn. The level of income which can be expected from the market is also uncertain. One response to these issues at the farm level is to reduce inputs and sheep numbers (extensify) in an attempt to maintain economic viability, with the potential for assistance of specific schemes to compensate farmers and estate owners.

These moves towards extensification may be perceived to benefit the native flora in hill communities. However, as preferred species are likely to continue to be grazed heavily and nonpreferred species less so, some detrimental changes may also occur. The objectives of this work were to monitor the changes which occurred in the vegetation of semi-natural hill pastures as a consequence of extensification policy.

\section{Material and methods}

This work is part of a 5-year study to determine the effects of extensification in hill sheep farming systems on animal welfare/production, socioeconomic viability and the flora of indigenous hill and upland pastures. The project covers 2160 ha of Kirkton and Auchtertyre Farms, Crianlarich, west Perthshire. The extensification area includes part of the Ben Hesgarnich site of special scientific interest. Botanical assessment started in April 1990 and will continue, initially, to 1995 . The two production systems in which the flora are being studied are as follows.

\section{(a) Moderate input system (control)}

This is the existing system with a high level of management input and sheep numbers (1.1 ewes per ha) with supplementary feeding of ewes according to age and scanned lamb numbers. (b) Extensified system

Sheep numbers were reduced by $30 \%$ ( 0.7 ewes per ha) in this system and all inputs, including supplementary food and labour, are reduced to a minimum.

Within both systems (adjacent glens) seven major plant communities have been identified, which are characterized by: (1) herb-rich Fescue/Agrostis; (2) Nardus stricta; (3) Juncus acutiflorus; (4) Trichophorum cespitosum; (5) Eriophorum angustifolium (blanket peat); (6) Vaccinium myrtillus; and (7) Calluna vulgaris.

Twenty $1-\mathrm{m}^{2}$ permanent quadrats were randomly placed within each community in both systems. Each quadrat is subdivided into 25 squares and all species were recorded in each square along with a ground cover score of the main species. Change in the diversity and abundance of flora will be recorded by returning to these quadrats over time. The baseline species data were computer logged and analysed using detrended correspondence analysis (DECORANA; Hill, 1979a) and two-way indicator species analysis (TWINSPAN; Hill, 1979b).

Sheep exclusion areas were established in the extensified system to determine the effects of eliminating sheep grazing on the abundance of heather. Herbage heights (Hill Farming Research Organisation swardstick), are recorded in each community during the season and biomass and gross botanical composition are estimated in April and November each year.

\section{Results and discussion}

This work is at an early stage and firm conclusions cannot be drawn. However, trends are appearing in the data which have already been collected. There is a general increase in herbage height in all the communities being monitored in the extensified system, compared with the control (Table 1). The 
Table 1 Herbage heights on 29 July 1992 and biomass in Novembr 1991 in each community

\begin{tabular}{|c|c|c|c|c|c|}
\hline \multirow[b]{2}{*}{ Community } & \multicolumn{2}{|c|}{ Herbage height $(\mathrm{cm})$} & \multirow[b]{2}{*}{ s.e.d. } & \multicolumn{2}{|c|}{ Biomass (t dry matter per ha) } \\
\hline & Control & Extensified & & Control & Extensified \\
\hline Herb-rich & $3 \cdot 3$ & $4 \cdot 3$ & $0 \cdot 32$ & 1.09 & 1.09 \\
\hline Nardus & $11 \cdot 8$ & $12 \cdot 3$ & 0.65 & $2 \cdot 37$ & $2 \cdot 48$ \\
\hline Juncus & $39 \cdot 7$ & $28 \cdot 4$ & $2 \cdot 04$ & $1 \cdot 54$ & $1 \cdot 37$ \\
\hline Trichophorum & $11 \cdot 2$ & $13-1$ & $0 \cdot 67$ & $1 \cdot 02$ & $1 \cdot 22$ \\
\hline Eriophorum & $10 \cdot 3$ & $11 \cdot 2$ & 0.51 & $1 \cdot 12$ & 1.86 \\
\hline Vaccinium & $6 \cdot 7$ & $8 \cdot 1$ & $0 \cdot 37$ & 2.07 & 1.98 \\
\hline Calluna & $4 \cdot 5$ & $5 \cdot 0$ & $0 \cdot 32$ & $1 \cdot 21$ & 1.46 \\
\hline Non-specific herbage in all communities & $4 \cdot 7$ & $6 \cdot 9$ & $0 \cdot 23$ & & \\
\hline
\end{tabular}

exception to this is the height of Juncus acutiflorus, which is significantly higher in the control glen $(P<0.001)$. The increase in herbage height in the extensified glen had reached statistical significance (at least $P<0.05$ ) by 29 July 1992 for Calluna vulgaris, Vaccinium myrtillus and non-specific herbage in all communities.

Biomass measurements taken in November 1991 suggested that the reduction in stocking rate in the extensified system made 1 year earlier was already leading to higher standing herbage mass in those communities of the extensified system dominated by Nardus stricta, Trichophorum cespitosum, Eriophorum angustifolium and Calluna vulgaris.
No differences between the communities of each system had been detected for grass botanical composition by November 1991 and the possible effects of extensification on the diversity and abundance of specific species will only become apparent when permanent quadrats are revisited.

\section{References}

Hill, M. O. 1979a. DeCORANa: a FORTRAn program for detrended correspondence analysis and reciprocal averaging. Ecology and Systematics, Cornell University, Ithaca, New York.

Hill, M. O. 1979b. TWINSPAN: a FORTRAN program for arranging multivariate data in an ordered two-way table by classification of the individuals and attributes. Ecology and Systematics, Cornell University, Ithaca, New York. 